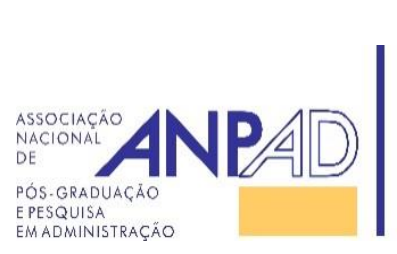

Available online at http://www.anpad.org.br/bar

BAR, Rio de Janeiro, v. 14, n. 1, art. 2, e160093, 2017

\title{
Networks, R\&D Projects and Subsidiary Behavior in a Host Country
}

Camila Franco ${ }^{1}$ Samuel Façanha Câmara Ronaldo Couto Parente ${ }^{3,4}$

Universidade Federal do Rio de Janeiro ${ }^{1}$ Universidade Estadual do Ceará ${ }^{2}$ Florida International University ${ }^{3}$ Fundação Getulio Vargas, Escola Brasileira de Administração Pública e de Empresas ${ }^{4}$

Received 26 September 2016; received in revised form in 23 January 2017; accepted in 6 February 2017; first published online 7 March 2017.

Editor's note. Marcia Dutra Barcellos served as Action Editor for this article. 


\begin{abstract}
This article aims to verify how multinational subsidiaries establish their networks in a host country. The literature addresses only networks formed between the subsidiary and its mother and sister companies. However, to consider the external network is essential, because the subsidiaries are not a mere receptor of knowledge from the headquarters, they develop their own capability for creating knowledge and innovation for the multinational. To examine the creation of these networks, this paper focuses on two subsidiaries located in Brazil belonging to a group that carries out $R \& D$ projects in partnership with several organizations in the country and creates research and development networks in their sector. To analyze the network characteristics, the authors used Ucinet and NetDraw software and found the following results: (a) geographic distance is a driver in establishing partnership among subsidiaries and executor organizations; (b) the majority of the relationships are tied between a company and a research organization, showing that theoretical knowledge and practical experience are considered by companies to develop and market project outcomes; and (c) although the subsidiaries belong to the same group, they do not have strong ties.
\end{abstract}

Key words: networks; subsidiaries; R\&D; technological capabilities. 


\section{Introduction}

Researchers (Ambos, Andersson, \& Birkinshaw, 2010; Andersson, Dellestrand, \& Pedersen, 2014; Cantwell \& Mudambi, 2011; Lorenzen \& Mudambi, 2013; Mudambi, Pedersen, \& Andersson, 2014; Yamin \& Andersson, 2011) have increasingly studied subsidiaries of multinationals and their impacts and relationships with the actors and host countries, demonstrating their growing importance for literature and economic analysis. The directed view on subsidiaries has been emphasized in different ways, but especially, as in the focus of this article, on matters related to the relationships formed by these companies. This is not only in the internal network, but extends to existing partnerships in their host country, the so-called external networks (Andersson, 2003). Achcaoucaou, Miravitlles and LeonDarder (2014) point this out when discussing the subsidiary's role of dual embeddedness, complementing the work by Yamin and Andersson (2011) who stressed the importance of this type of company for the multinational company (MNC), considering this dual relationship it establishes. S.-H. Lee and Song (2012) not only discussed the uncertainties in the host country where the subsidiary is inserted, but also undertook an investigation on the impact that some factors in external and internal subsidiary relationships have on its performance.

While discerning the importance of the topic and the existence of some research done on it, there is still very little in literature referring to the analyses on networking by subsidiaries in their host countries. As Achcaoucaou and Miravitlles (2012) say, many studies analyze the role of the subsidiary separately and therefore neglect the effects of possible networks around it, particularly those effects arising as a consequence of simultaneous interplay among the actors networking with these subsidiaries. Although the authors try to fill this gap, they concluded that there is still a need to further investigate the effect of the external interplay of subsidiaries and, therefore, the effects of the network and interplay with the MNC subsidiaries are not fully developed (Achcaoucaou, Miravitlles, \& Leon-Darder, 2014).

According to Lorenzen and Mudambi (2013), MNCs are organizational networks operating their own systems, forming subsidiaries in different clusters to produce goods, services and know-how. The authors also state that there is widespread literature on international business that analyzes the pros and cons of networking, but an in-depth understanding of the social network is seldom used. In other words, it is a known fact that networking offers benefits and also some disadvantages for companies, but analyzing how the relationship within these networks occur, what kind of interplay happens and knowing the actors involved requires more in-depth studies.

Andersson, Mats and Holm (2002) say that, with regard to literature on networks, including multinationals and subsidiaries, many articles address the overall environment without taking into consideration their complexity, dynamism and wealth of resources. These studies usually focus only on the subsidiary's interplay with its parent company and sister companies.

Therefore, closer attention should be given to the subsidiary's internal skills, to understand how it procures knowledge, forms partnerships and develops new processes and products. This should be done before analyzing how it is related to its parent and sister companies and their networking relationship in the countries hosting their subsidiaries.

Based on the context of the gap in literature and on the actual relevance of the topic, this article endeavors to answer the following research question: how do subsidiaries build their networking sites in emerging economies, such as Brazil? The objective, therefore, of this article is to ascertain how subsidiaries build their networks within a host country that is an emerging economy. To achieve this, the study herein researched two electricity company subsidiaries from the same corporate group situated in Brazil in the states of Ceará and Rio de Janeiro.

In the process of achieving this objective it will be possible to reproduce the network built by the subsidiaries based on the Research \& Development $(\mathrm{R} \& \mathrm{D})$ projects designed by them, creating their own statistical analyses and observing the frequency of the type of organizations present, as well as their geographical focus. Since they are two subsidiaries belonging to the same corporate group, this study 
will also enable analysis of the interplay between them and their partners. This information will help fill part of the gap in literature inasmuch as it will provide specific characteristics about the network built by the subsidiaries, comprising therefore the main theoretical contribution originating from this study.

Furthermore, it is also possible to highlight this study's contribution to the institutional and managerial field, since it allows the managers of these organizations in the electricity sector to see which organizations are related to each other and working in an integrated manner on their R\&D projects and networking, as well as how these organizations work with other companies, institutes and universities. This can somehow contribute to their being able to more effectively identify their partners in research and development projects and how they behave in building these R\&D networks.

The article is structured as follows: after this introduction the theoretical benchmark is presented referring to networking, its concepts, development, applications and contributions, as well as some studies that relate this topic to the subsidiaries. Next, the research methodology adopted is addressed, followed by the main findings. Finally, the authors offer their final considerations, with emphasis on their contributions and suggestions.

\section{Literature Review}

Granovetter (1985) states that organizations are social constructs and the product of actions by individuals immersed in relationships. For the author, economic efficiency does not occur in a vacuum but depends on social contextualization. From these considerations, a conclusion is reached that a company's strategies are (and should be) directly related to its networks and relationship, and this is why it has more chances of obtaining information and know-how and sensing the opportunities in the environments through its interplay with partners (Granovetter, 1985).

The concept of social networks has already been discussed by a number of researchers, including sociologists and anthropologists, but the first to be reported was the concept given by Barnes (1954, p. 44), where he referred to these as "a set of points, some of which are connected by lines". These points are considered to be individuals and the lines represent their interplay.

Thus, a social network means the connections made among specific groups, where the characteristics of these connections can be used to explain the social behavior of such groups. Håkansson and Johanson (1988) argue that networks are structures combining activities and resources in specific formats.

Another similar concept on the subject of networks, evolving as time goes by, is by Scott (2000), who defines it as a set of nodes connected by a set of loops. The nodes are the actors or players of the network and the loops the relationships established with each other (Liu \& Chaminade, 2010).

The limitation that companies encounter in mastering all stages of the value chain and their own management capabilities in every area (Casarotto \& Pires, 1998) can be bypassed by forming a network, in which the organizations can share and cooperate in carrying out the initial and final activities of such a chain. According to Balestrin, Verschoore and Reyes (2010) the main gains generated by a network for companies are learning, success and innovation.

Networking can help meet a series of requirements, as follows: to match skills and use the knowhow of other companies; to share onus in undertaking technological research, sharing development and acquired know-how; to share risks and costs of exploring new opportunities, undertaking experiments together; to offer a more diversified and top quality product line; to exert more pressure on the market; to share resources; to strengthen purchasing power, and to be strong enough to operate in international markets (Amato, 2000). 
The view of networking generally creates a notion that economic actions are influenced by the social context in which they are included, and that the actions can be influenced by the position of the actors in the network (Gulati, 1998). The importance of the actor does not lie in his or her characteristics but in the contribution offered to the network, more efficiently processing and distributing information and know-how.

To understand how actors and their positions influence a network's operation it is necessary to analyze that network, where it is possible to assess the statistical relations of the phenomena, including information about the relationships between the units of analysis (Rossoni \& Graeml, 2009). Freeman (2004, p. 2) defines the analysis of social networks as "the structural approach based on the study of interplay among the social actors" and the objective of this analysis is "to discover different types of patterns and determine the conditions in which these patterns appear and their consequences". The degrees examined in network statistical analyses are shown in Table 1.

Table 1

Degrees for Network Analysis

\begin{tabular}{ll}
\hline \multicolumn{1}{c}{ Degree } & \multicolumn{1}{c}{ Definition } \\
\hline Density & $\begin{array}{l}\text { Percentage value of network connectivity. Calculated by the quotient between the number } \\
\text { of existing relationships and number of possible relationships. }\end{array}$ \\
\hline Centrality & Number of actors to whom a single actor directly related. \\
\hline Intermediation & Possibility that an actor has to intermediate communications between other actors. \\
\hline Proximity & An actor's capacity to reach all nodes in the network. \\
\hline
\end{tabular}

Note. Source: based on Alejandro, V. A., \& Norman, A. G. (2005). Manual introdutório à análise de redes sociais (pp. $17-$ 26). Toluca: Universidad Autonoma Del Estado de Mexico.

Networking is a competitive edge for companies that know how to use it. Achcaoucaou et al. (2014) explain that the reason why some subsidiaries achieve a better and principally innovative performance can be explained by the frequency, depth and quality of the connections these companies establish with their local partners.

Recent studies have shown that adopting cooperative strategies has become an increasingly common reality among organizations worldwide (Schifrin, 2001). Yoruk (2011) undertook a study to investigate how an element in a network changes over time and how this change can be influenced by changes in further developing the companies' technological capabilities. Accordingly, the author uses what he calls knowledge links as a tool for companies to use in their technology projects to introduce new technologies of the product and/or process. To analyze these knowledge links the author searched in technological projects run by companies for existing knowledge flows within each one, and to do so investigated the knowledge links - interaction between the company and any actor in the innovator system.

The author states that these knowledge links procured by companies from networking enable the company to increase its capabilities. He suggests that for future studies a more extensive analysis is to be made of this study and complement with coevolutionary interplay among the corporate capabilities and structure of the knowledge network.

Networking by subsidiaries has become an increasing reality in literature, mainly due to the fact that international business literature has identified, with focus on R\&D activities, the emergence of technologically advanced subsidiaries playing a more creative role, as defined by Cantwell and Mudambi (2005) (as cited in Blomkvist, Kappen, \& Zander, 2010). This change perceived in the role of the subsidiaries is important, since it demonstrates their role in globalizing innovation, and consequently in MNC innovator capacity (Phene \& Almeida, 2008). 
Santangelo (2009) claims that the creation of local links by subsidiaries is greater when they have the creative skill within their organizational structure. According to Andersson (2003), a subsidiary absorbs know-how through its business links with local partners that represent a valuable source of technological skills to help it contribute to the MNC's global capabilities. Further integration of subsidiaries in networks is able to create new knowledge for the entire multinational (Achcaoucaou \& Miravitlles, 2012). To analyze the factors that could influence networking, some hypotheses are provided below to help in the process of analyzing the networks.

The first point to be discussed herein is the geographical distance at the time when the partnership is established to implement the projects. Some companies only go beyond the physical distance and also examine something called in literature psychic distance ("the sum of factors preventing the flow of information to the market" - Johanson \& Vahlne, 1977, p. 24) which takes into account factors such as industrial structure, education system, economic development and so on.

Since this study analyzes organizations in the same country, and that, although Brazil has some regional differences, physical distance (geographical) is the major factor influencing the partnering among organizations.

Cantwell and Mudambi (2011) discuss in their article the so-called psychic attraction, which tends to increase the proximity of mutual ties and increase the probability of embeddedness in mutual projects.

The proximity factor helps the question of supervision, in the case of developing projects, when two organizations work closely together. It is possible there is more interaction between them with equal participation in implementing the project's stages.

On the other hand, the existing geographical distance between organizations could create an unequal or even incomplete work relationship. It is possible that a project with many stages, when implemented by several organizations far from each other, has stages shared among them, so that each part is implemented solely by one organization and so on, and there will not be much interplay at every stage of the project. Moreover, the coordination factors could be ignored or neglected.

Therefore, the first hypothesis of this study is developed as follows:

H1: The subsidiaries establish their partnerships with the geographically nearest organizations.

Another important factor for understanding network analysis concerns the partnering. As mentioned by Amato (2010), networking enables companies to explore less developed capabilities when working together with organizations that have capabilities that they lack. To combine skills and use the know-how of other companies; to share onus when doing technological research, sharing the development and expertise; to offer a very diversified top-quality product line; to share resources, and to strengthen purchasing power are some points that the author mentions as networking's positive outcomes.

To match the right partners for a certain activity is also essential for companies. The role of each type of organization has an influence on the final result aimed by the company when looking to form partnerships.

In the case of R\&D projects focusing on the electricity sector, it is necessary to include some specific types of know-how to develop the project. The innovator capability is key to the research and development area, but since the studies on this topic mention innovation, is a necessity that needs to be commercially feasible. Therefore, it is also necessary to have organizations present in this partnership that are capable not only of research and developing the product, but also capable of adapting it to market requirements.

Organizations of the university type, research center, research institute and others along this line are based fundamentally on developing ideas, while commercially oriented organizations, such as 
companies, since they are closer to demand, are able to understand what the existing market requirements are.

It is, therefore, possible to formulate a second hypothesis for this study, bearing in mind the role of each partner organization.

H2: MNC subsidiaries look to develop R\&D projects in a network with partners focusing on the market (corporate) associated with organizations focusing on research (universities and research centers).

A last important factor concentrates on the particularity of working with subsidiaries. According to Andersson et al. (2002), literature on networking and subsidiaries has worked hard on the relationship that they establish with their parent and sister companies. The network formed by the subsidiary and other actors in the environment is also very important since it enables the subsidiary to develop its creative skills to further develop its capabilities (Almeida \& Phene, 2004).

However, if the subsidiary is able to form a closer relationship both with the organizations present in the host country where it is installed, and with its sister companies, its capabilities could be leveraged even more, mainly if the latter are included in the same network.

Some multinationals set up more than one subsidiary in the same place, thereby enabling them to talk to each other and develop their skills together. When subsidiaries, in particular, form their own external networks, it could be imagined that it is highly possible that they have partners in common, since they have similar goals. Therefore, by aggregating these views, the last hypothesis of this study is formulated as follows.

H3: Sister-subsidiaries (belonging to the same multinational parent company) in the same host country partner with each other when establishing their private networks.

Based on these hypotheses it is possible to draw up a model showing the main points related to the network analysis made by these subsidiaries from $R \& D$ projects (Figure 1 ). 


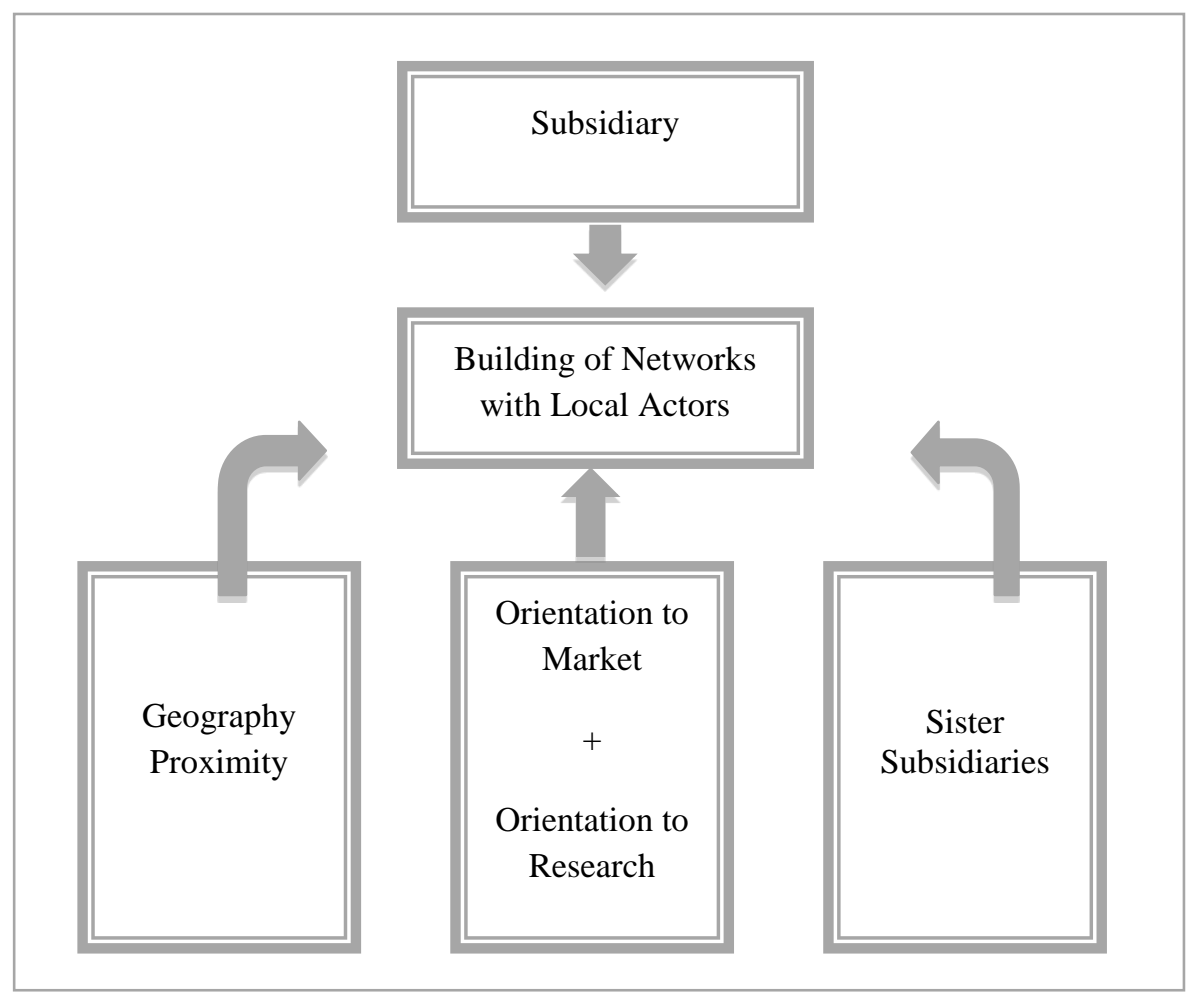

Figure 1. Model for Network Analysis

Source: Elaborated by authors.

\section{Methodology}

Inspired by the work by Yoruk (2011), who analyzes corporate networking based on knowledge links that implement technological projects, and with a view to achieve the goals listed herein, the authors developed a case study on two electricity subsidiaries located in the states of Rio de Janeiro (AMPLA) and Ceará (COELCE), concerning R\&D projects undertaken by both. These companies, under Brazilian Law 9.991/2000 that requires a minimum percentage of the Net Operating Income (NOI) of electricity concessionaires to be allocated to R\&D projects, are looking for partnerships for such projects (Lei n. 9.991, 2000).

The R\&D projects "are destined to the qualification and the technological development of the companies of electrical energy, aiming at the generation of new processes or products, or the improvement of its characteristics" (Agência Nacional de Energia Elétrica [ANEEL], 2012, p. 14).

From these projects, links with various organizations are made for partnering. In this paper, these organizations are called partner organizations. These links represent the sample. Data collection for the case study included 39 interviews with the R\&D managers responsible for the subsidiaries (AMPLA and COELCE) and the partner organizations. Besides interviews, managers provided the R\&D project database during the period from 2010 to 2013.

To analyze these data the links were examined referring to the type of organization with which the subsidiary partnered and where this organization is situated, developing a Social Network Analysis (SNA). Networks were mapped based on Ucinet and NetDraw software in order to view the statistical analyses that the network offers (degrees of centrality, proximity, intermediation and density).

The SNA is a technique based on the study of the link between present actors, having as the objective to unveil the various types of existing patterns and determine the conditions in which they 
appear and their consequences (Freeman, 2004). In SNA patterns exist that help in the study of networks, such as the level of density, centrality, intermediation and centration. From the calculation of these standards it is possible to understand the behavior of the actors present in the network. Table 2 present the procedures to calculate the statistics about the network.

Table 2

How to Calculate the Statistics Network

\begin{tabular}{ll}
\hline Degree & How to calculate \\
\hline Density & $\begin{array}{l}\text { Divide the number of existing relationships (ER) between possible relationships (PR) } \\
\text { and multiply by } 100(\mathrm{D}=\mathrm{ER} /(\mathrm{PR} \times 100)) . \\
\\
\text { Number of possible relationships (PR): multiplies the total number of actors by total } \\
\text { minus 1 (PR = TNA x (TNA-1)). }\end{array}$ \\
\hline Centrality & Number of actors with which one actor is direct linked. \\
\hline Proximity & Sum of distances between an actor and the others. \\
\hline Intermediation & Count the number of times an actor appears on the path connecting all network pairs. \\
\hline
\end{tabular}

Note. Source: based on Alejandro, V. A., \& Norman, A. G. (2005). Manual introdutório à análise de redes sociais (pp. 1726). Toluca: Universidad Autonoma Del Estado de Mexico.

Summarizing this section, Table 3 present the main information about the research methodology.

Table 3

Summary of Research Methodology

\begin{tabular}{ll}
\hline Law 9.991/2000 & Basis for the research \\
\hline Energy companies analyzed & AMPLA and COELCE \\
\hline R\&D Projects & $\begin{array}{l}\text { "are destined to the qualification and the technological development of } \\
\text { the companies of electrical energy, aiming at the generation of new } \\
\text { processes or products, or the improvement of its characteristics" } \\
\text { (ANEEL, 2012, p. 14). }\end{array}$ \\
\hline Links & $\begin{array}{l}\text { Partnerships between an energy company and partners organization to } \\
\text { developed projects. }\end{array}$ \\
\hline Partners Organizations & $\begin{array}{l}\text { Research Institutes; Universities; NGO; Associations; Research Centers; } \\
\text { Research Nucleus; and Foundations }\end{array}$ \\
\hline Data Collection & Case Study \\
\hline Data Analysis & Social Network Analysis \\
\hline
\end{tabular}

\section{Data Analysis and Results}

In this section the following results will be presented: descriptive analysis, detailing the projects surveyed; Social Network Analysis, showing the results of the networks built from the partnerships realized for the development of R\&D projects; case study interviews, with the presentation of some qualitative data collected from the interviews conducted with the objective of complementing the results derived from the study of the networks. 


\section{Descriptive analysis}

AMPLA has a total of 28 and COELCE a total of 44 R\&D projects, for a total of 72 together. The total of links (88) made between AMPLA/ COELCE and the partners organizations is the sample of this study.

Altogether 49 partner organizations were found, including research institutes, companies, universities and so on, as shown in Table 4. It is also possible to see the quantity of projects completed for each organization. This information represents the knowledge links established with each organization involved in the network.

Table 4

Quantity of Partner Organizations and Quantity of Projects Respectively

\begin{tabular}{|c|c|c|c|}
\hline \multicolumn{2}{|c|}{ Total Quantity of Partner Organizations } & \multicolumn{2}{|c|}{ Quantity of Projects by Partners Organizations } \\
\hline & TOTAL & & TAL \\
\hline Companies & 22 & Companies & 34 \\
\hline Research Institutes & 7 & Research Institutes & 20 \\
\hline Universities & 8 & Universities & 14 \\
\hline Research Centers & 3 & Research Centers & 7 \\
\hline Associations & 4 & Associations & 7 \\
\hline NGO & 1 & NGO & 1 \\
\hline Research Nucleus & 1 & Research Nucleus & 1 \\
\hline Foundation & 3 & Foundations & 4 \\
\hline TOTAL & 49 & TOTAL & 88 \\
\hline
\end{tabular}

Note. Source: Research data.

Table 5 provides the number of projects implemented by the subsidiaries, organized by geographical location. Table 6 an association is made between the type of organization present in the partnership and the city where it is located. 
Table 5

Quantity of Projects by Cities

\begin{tabular}{|c|c|c|c|}
\hline REGION & STATE & CITY & TOTAL \\
\hline \multirow[t]{12}{*}{ Southeast } & \multirow[t]{3}{*}{ São Paulo } & São Paulo & 6 \\
\hline & & Campinas & 7 \\
\hline & & Sorocaba & 2 \\
\hline & \multirow[t]{6}{*}{ Rio de Janeiro } & Rio de Janeiro & 24 \\
\hline & & Niterói & 1 \\
\hline & & Petrópolis & 2 \\
\hline & & Saquarema & 1 \\
\hline & & Seropédica & 1 \\
\hline & & Campo dos Goytacazes & 1 \\
\hline & \multirow[t]{3}{*}{ Minas Gerais } & Juiz de Fora & 1 \\
\hline & & Itajubá & 1 \\
\hline & & Belo Horizonte & 1 \\
\hline \multirow[t]{2}{*}{ South } & Paraná & Curitiba & 5 \\
\hline & Santa Catarina & Florianópolis & 1 \\
\hline Midwest & Distrito Federal & Brasília & 1 \\
\hline \multirow[t]{5}{*}{ Northeast } & Recife & Pernambuco & 2 \\
\hline & \multirow[t]{4}{*}{ Ceará } & Eusébio & 2 \\
\hline & & Aquiraz & 1 \\
\hline & & Sobral & 1 \\
\hline & & Fortaleza & 27 \\
\hline TOTAL & & & 88 \\
\hline
\end{tabular}

Note. Source: Research data. 
Table 6

\section{Relation between the Number of Organizations Present in Partner Organizations by Cities}

\begin{tabular}{|c|c|c|c|c|c|c|c|c|c|}
\hline CITY & Associations & ResearchCenters & Companies & Foundations & $\begin{array}{l}\text { Research } \\
\text { Institutes }\end{array}$ & $\begin{array}{c}\text { Research } \\
\text { Nucleus }\end{array}$ & NGO & Universities & Total \\
\hline Aquiraz & 0 & 0 & 0 & 0 & 1 & 0 & 0 & 0 & 1 \\
\hline Belo Horizonte & 0 & 0 & 1 & 0 & 0 & 0 & 0 & 0 & 1 \\
\hline Brasília & 1 & 0 & 0 & 0 & 0 & 0 & 0 & 0 & 1 \\
\hline Campinas & 0 & 1 & 1 & 1 & 1 & 0 & 0 & 0 & 4 \\
\hline Campo dos Goytacazes & 0 & 0 & 1 & 0 & 0 & 0 & 0 & 0 & 1 \\
\hline Curitiba & 0 & 0 & 1 & 0 & 1 & 0 & 0 & 0 & 2 \\
\hline Eusébio & 0 & 0 & 1 & 0 & 0 & 0 & 0 & 0 & 1 \\
\hline Florianópolis & 0 & 0 & 1 & 0 & 0 & 0 & 0 & 0 & 1 \\
\hline Fortaleza & 2 & 1 & 4 & 0 & 3 & 1 & 0 & 1 & 12 \\
\hline Minas Gerais & 0 & 0 & 1 & 0 & 0 & 0 & 0 & 1 & 2 \\
\hline Niterói & 0 & 0 & 1 & 0 & 0 & 0 & 0 & 0 & 1 \\
\hline Petrópolis & 0 & 0 & 0 & 0 & 0 & 0 & 0 & 1 & 1 \\
\hline Recife & 0 & 1 & 1 & 0 & 0 & 0 & 0 & 0 & 2 \\
\hline Rio de Janeiro & 0 & 0 & 6 & 1 & 0 & 0 & 0 & 5 & 12 \\
\hline São Paulo & 0 & 0 & 2 & 1 & 1 & 0 & 0 & 0 & 4 \\
\hline Saquarema & 0 & 0 & 1 & 0 & 0 & 0 & 0 & 0 & 1 \\
\hline Sobral & 0 & 0 & 0 & 0 & 0 & 0 & 1 & 0 & 1 \\
\hline Sorocaba & 1 & 0 & 0 & 0 & 0 & 0 & 0 & 0 & 1 \\
\hline Total & 4 & 3 & 22 & 3 & 7 & 1 & 1 & 8 & 49 \\
\hline
\end{tabular}

Note. Source: Research data. 


\section{Social network analysis}

By mapping the project networks of both the subsidiaries and partner organizations it was possible to measure the degree of density, taking into consideration the existing and possible networking relationships. This network, with 72 projects, including the two subsidiaries and 49 partner organizations, made 88 links leading to a $1.7 \%$ degree of density, which is low connectivity power, considering that this figure can vary from $0 \%$ to $100 \%$.

This first network (Figure 2) shows that the subsidiaries, although they belong to the same group, carry out activities referring to the same sector and have the same manager in charge of the $R \& D$ projects, but do not form links with each other. It is noted that the networks containing more relationships are made up of projects developed solely by one or the other subsidiary, with no interplay between them. Consequently, Hypothesis 3 is disproven.

Figure 2 show that 56 projects are developed just by one company in partnership with the subsidiary (COELCE or AMPLA).

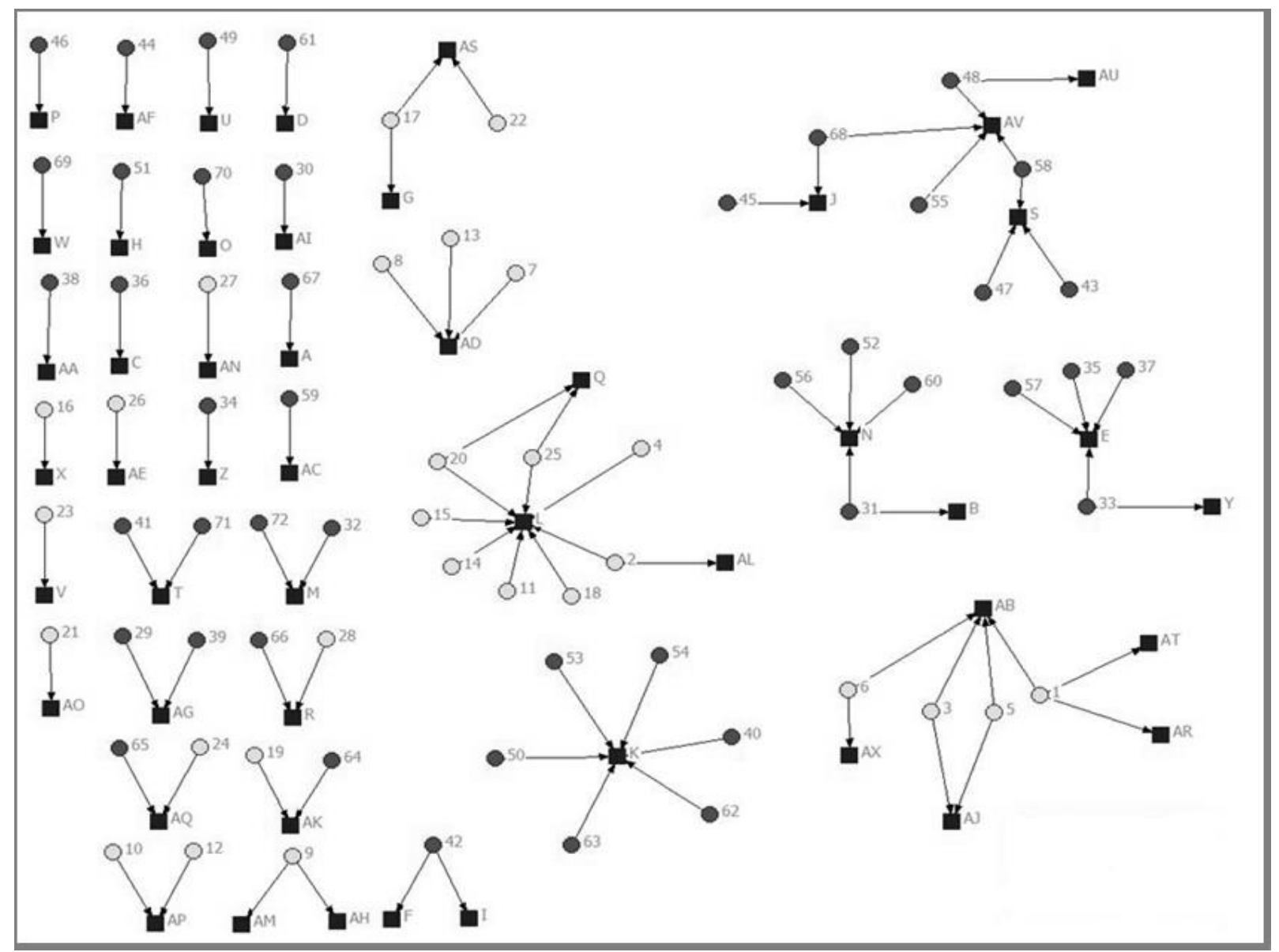

The numbers symbolize the R\&D projects, developed by specified subsidiaries (AMPLA and COELCE). The letters are the partner organizations in carrying out such projects.

$$
\text { - AMPLA }
$$

- COELCE

Figure 2. General Network of Two Subsidiaries Source: Research data. 
To observe the network comprising each subsidiary separately, the relationship networks of each were built separately. A very low degree of density was found of only $3.7 \%$ for network 1 (Ampla) Figure 3 - and $2.3 \%$ for network 2 (Coelce) - Figure 4.

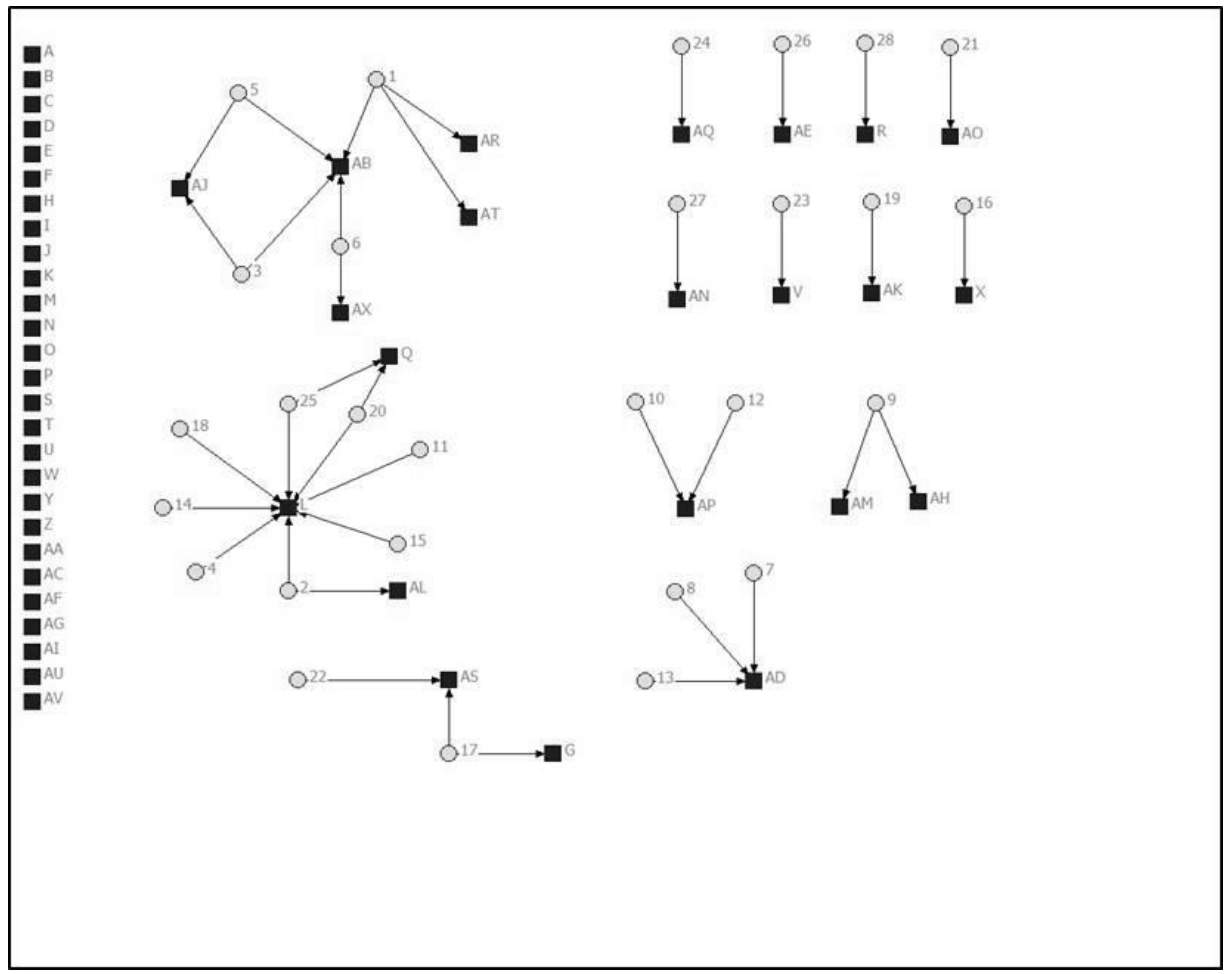

Figure 3. AMPLA Network

Source: Research data.

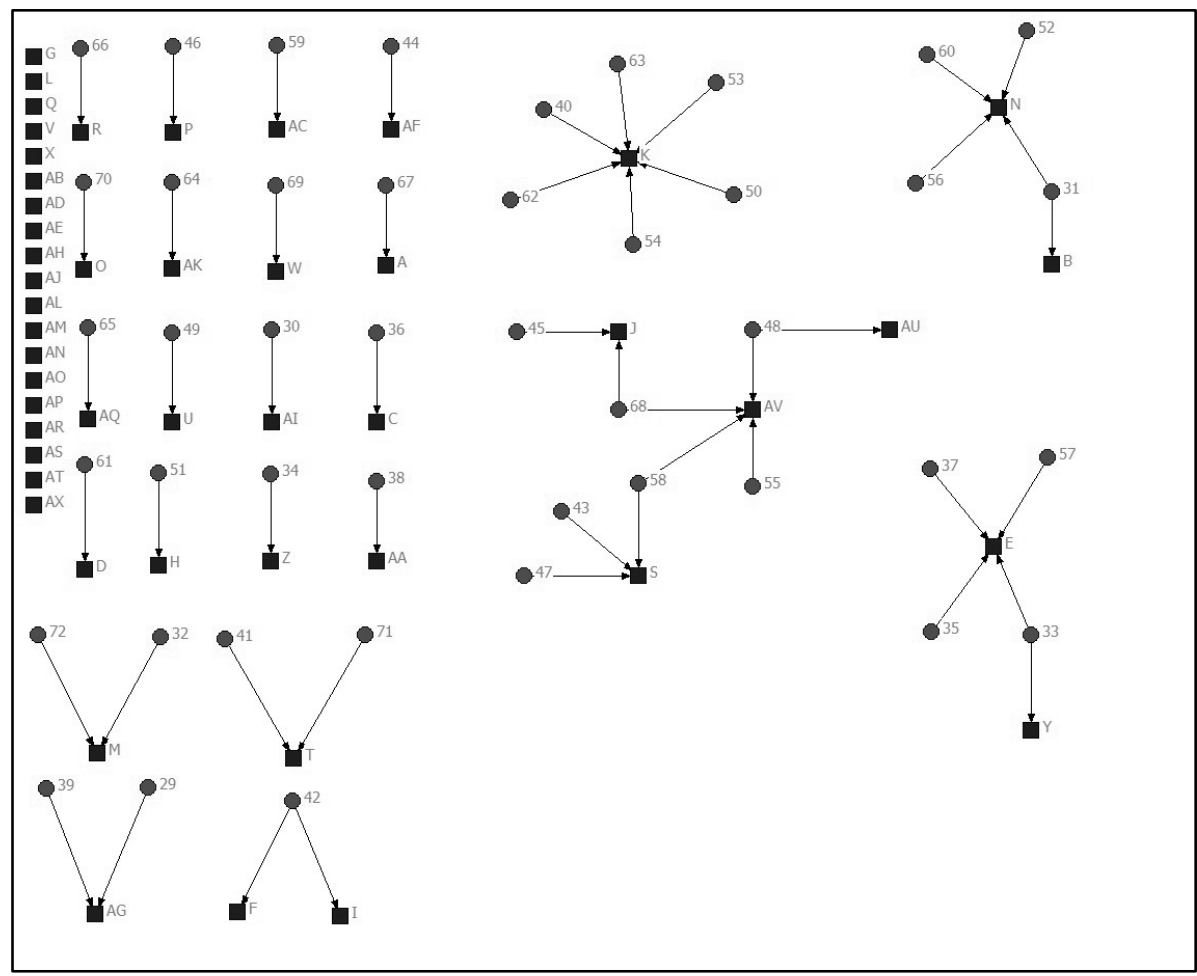

Figure 4. COELCE Network

Source: Research data. 
In order to verify Hypothesis 1, a network was also built to observe the cities where the projects have been or are implemented; cities where each partner organization for implementing the work operates.

This network clearly shows that the major concentration is in Fortaleza and Rio de Janeiro (see Figure 5), where the subsidiaries are installed (also, Ampla is in Niterói, a municipality in metropolitan Rio de Janeiro). Partnering is found in some other cities throughout Brazil, but each had few developed projects. This information is confirmed because the quantity of actors in the network is linked to these two cities.

The subsidiary in the state of Rio de Janeiro (Ampla) concentrates its partnering on cities in Southeastern Brazil, with few exceptions, while Coelce, although it focuses on the projects in Fortaleza, has partnerships in different regions of the country. These findings confirm Hypothesis 1 that partnering established in the projects is related to geographical distance; that is, companies farther from the subsidiary are normally not regarded as partners.

It is worth mentioning here that the partnering process is done in two ways. Both subsidiaries have a system on which the R\&D requirements are placed and the interested organizations can develop a project based on this demand. Alternatively, the subsidiary, having such a demand, directly looks for a partner organization to develop the project, bearing in mind its prior knowledge and its capabilities for implementing the project.

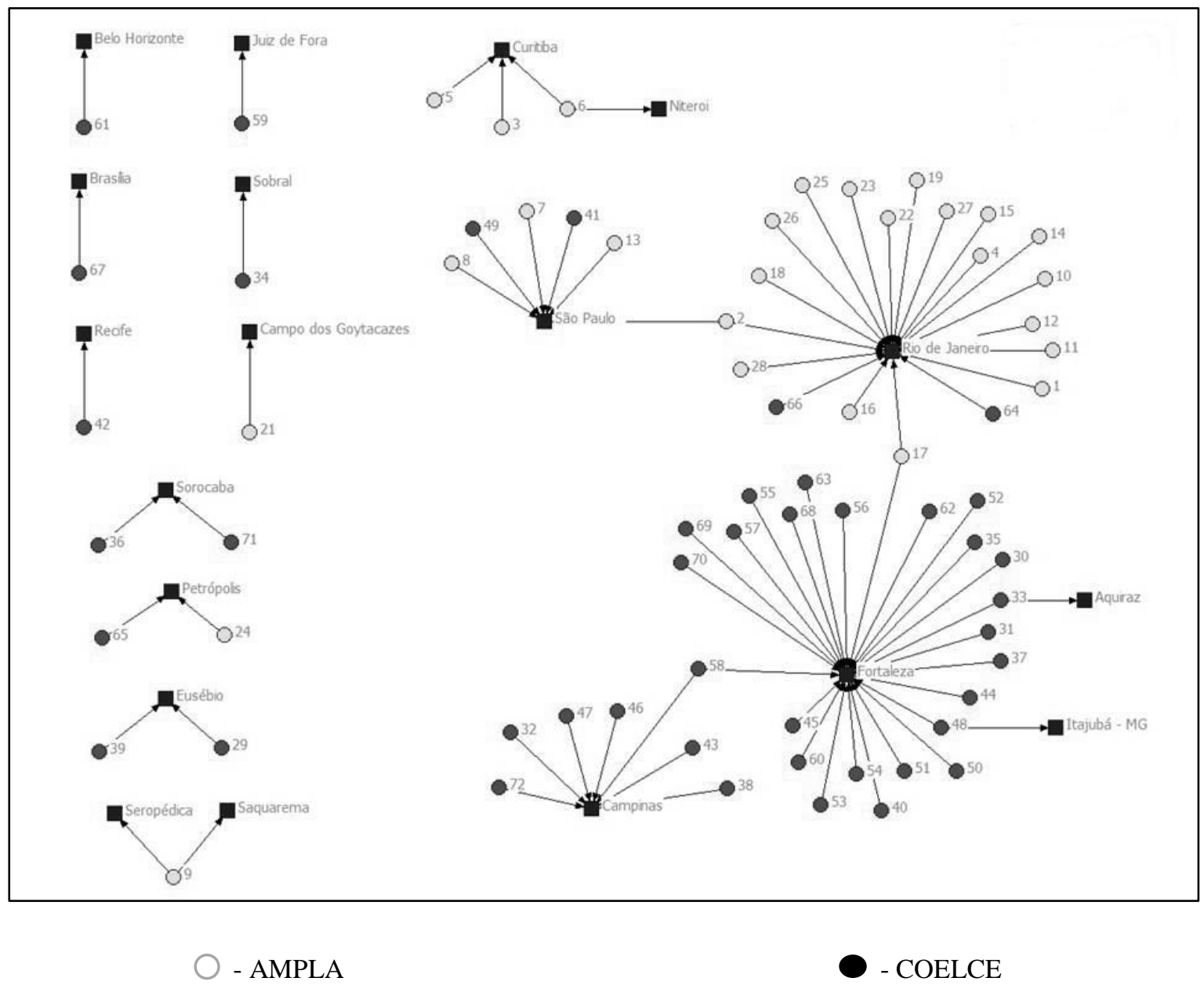

Figure 5. Network of Two Subsidiaries Organized by Projects and Cities of Execution Source: Research data. 
Figures 6 and 7 below represent the networks referring to the type of partner organization involved in implementing the projects. According to the analysis of these networks the arrival at general statistics of the network of partner organizations, which highlights a $2 \%$ degree of density, a $55 \%$ network centrality rate, with actor $\mathrm{AB}$ identified as the most central, that is, with the highest centralization degree; and the intermediation factor and proximity being highlighted for actors R, AQ and AK (company, university, university), which are project partners with both subsidiaries.

Figure 6 shows a large quantity of types of organization in this group of partners (NGO, research institutes, universities, company, etc.). When analyzing this network a noticeably large number of projects are being implemented by companies (it should be mentioned here that all are characterized as small enterprises) and by research institutes. This analysis confirms Hypothesis 2, which emphasizes the participation of research organizations and companies for developing the projects. This is no coincidence, but the subsidiary's intention is to be able to link the technical knowledge from research institutes with practical knowledge from companies. In other words, the possibility of producing and placing the project's result on the market is part of the process that is mainly reserved for companies.

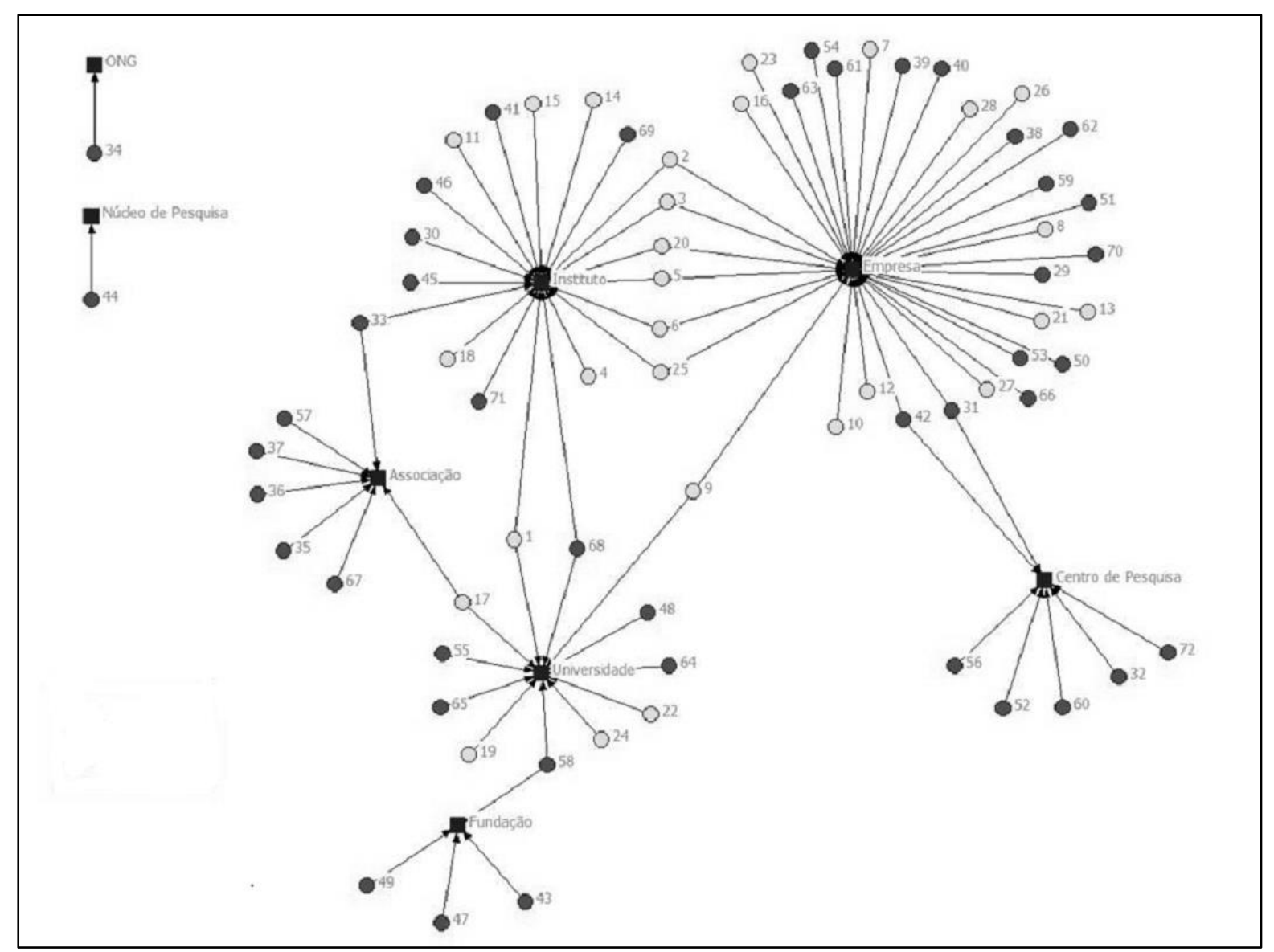

Figure 6. Network of Two Subsidiaries Organized by Projects and Kind of Organization Source: Research data.

Figure 7 provides a clearer view of why Hypothesis 3 is disproven; only three organizations intermediate between the two subsidiaries, connect the two networks, and permit some communication in developing these projects. 


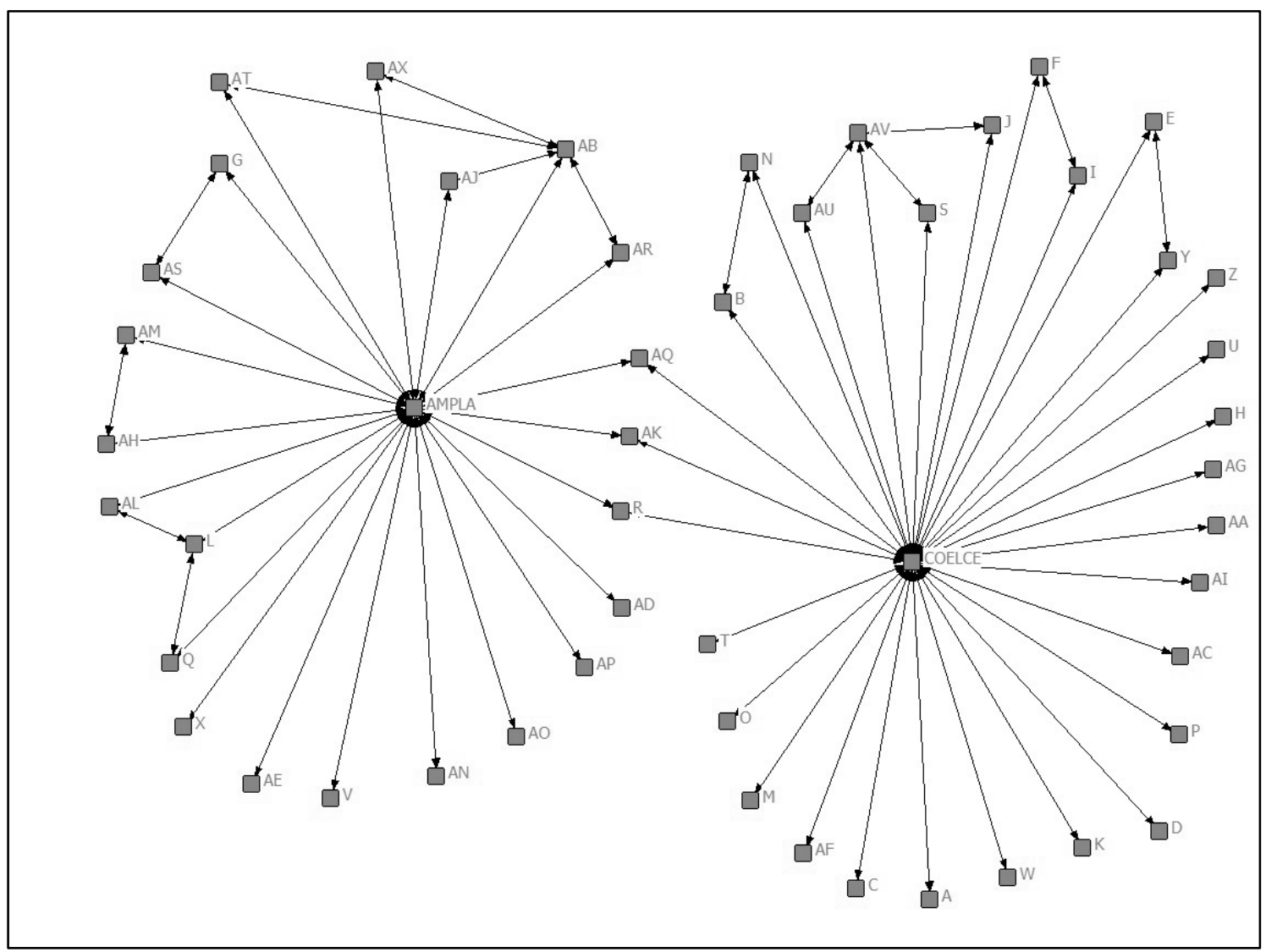

Figure 7. Network of Partner Organizations

Source: Research data.

\section{Case study interviews}

The interviews with the managers of the $R \& D$ projects provided information in addition to the available database. The manager of one of the energy companies emphasized the benefits of the partnership with universities in the development of projects, stating that: "The partnership with universities makes it possible to have a higher technical and theoretical degree for the development of solutions for the company".

When the interviews were made with the partner organizations, the managers' speeches focused on the benefits obtained through the partnership made with energy companies, which, because of visibility and credibility, helps the partners to stand out in the market. These considerations are based on the statements of two managers:

"After the partnership we had the opportunity to participate in some conferences and publicize not only the project on which it is working but also the company itself" (partner organization).

"The partnership helped give a start to the company" (partner organization).

The case study carried out in this research provided sufficient subsidies to understand the main results achieved with the formation of networks between energy companies and partner organizations.

\section{Discussion of Results}

Many of the projects (56 of 72) are implemented by only one organization as a partner (Figure 2), reducing the possibility of connecting with different types of actors. Only six networks are built with 
more than three links, and even then they are networks with no major interplay between the actors. The possible connectivity of being among the actors could be much better utilized. Nevertheless, it is possible to see some organizations as keys, that is, organizations present in implementing more than three projects, which emphasizes their major role in $\mathrm{R} \& \mathrm{D}$ development.

By analyzing the geographical environment formed by this network (the cities forming the network) it looks as if the organizations are restricted to their physical space and do not attempt to extend their knowledge to other regions, which would enable greater development of their capabilities. When they develop projects outside their geographical space, subsidiaries work on a very occasional basis, establishing projects particularly with organizations, instead of aggregating and increasing network connectivity.

It should be pointed out that the possibility of a project being implemented by more than one organization at the same time enables them to also develop their capabilities and knowledge by relating to various organizations. An example worth mentioning, and noticeable in Figure 6, is the university, most often present in a partnership either with a company, institute, foundation or association. The relationship established by universities adds positive results at the moment when it provides its students with more practical work on projects related to their research area, and also allows the university to join other environments that are not just academic.

\section{Conclusion}

The aim of this paper was to ascertain how subsidiaries build their networks within a host country is an emerging economy, and thus to answers the research question: how do subsidiaries build their networking sites in emerging economies, such as Brazil? These research results contribute to the literature with specific characteristics about the network built by the subsidiaries. Analyzing networking of a multinational's subsidiary in its host country helps understand how this company built its partnering and consequently developed its know-how and capabilities, which is positive for the parent company, considering that the results are transferred to it later (Almeida \& Phene, 2004). As Andersson et al. (2002) say, before understanding how knowledge flows from the subsidiary to the multinational, it is necessary to look at the company's internal skills, understand how it procures this know-how, and how it is developed within company capabilities to then be able to be transferred.

This study also contributes to expanding literature about external networks, analyzing the role of the subsidiaries not only individually but also taking into consideration the effects of networking by subsidiaries with local actors (Achcaoucaou \& Miravitlles, 2012). Even more so, this analysis is done in a developing country in the Americas. This is novel (Franco, 2014), as many studies of subsidiaries in developing countries focus on Asian regions (Ariffin \& Bell, 1999; Chang, Mellahi, \& Wilkinson, 2009; R. P. Lee, 2010).

This article enabled a view of how two subsidiaries of the same multinational, installed in the same host country, built their networks by developing R\&D projects. Some characteristics about these networks can be seen. There is a low connectivity between the actors, which is a negative point for the development of capabilities. The organizations appear to have geographical restrictions, because their connections are with the nearest organizations. It was only possible to observe the close relationship (88 relations with 49 partners), yet not diagnose where these partnerships were established, that is, how does the subsidiary increase its role in the environment where it is installed.

However, with the qualitative data from the interviews in the case study it is possible to perceive that the relations formed were seen as positive for both the energy company and the partner organizations, with several advantages.

Another result is about the type of organizations with which the subsidiaries formed networks, which shows the wealth of diversified knowledge acquired when involved with different organizations. 
The presence of universities in the network adds positive results at the moment when it provides students with more practical work on projects related to their research area, and also allows a university to join other environments that are not just academic.

A limitation of this study is that it do not look at the multinational, just at the subsidiaries. After fully analyzing how subsidiaries establish partnering in a host country, it would also be interesting to research how all the capability and know-how acquired is transferred to the multinational, noting whether the relationship with different types of organization, for example, influences this means of exchange. This paper also analyzed just 2 companies because of accessibility. Another limitation is about the sector analyzed. The choice for this sector is because it presents a singular and interesting characteristic for innovation research in that law forces energy companies to invest in $R \& D$ projects to stimulate innovation in the industry.

\section{References}

Achcaoucaou, F., \& Miravitlles, P. (2012). A double-network perspective on the evolution in subsidiary R\&D role: a matter of dual embeddedness. In A. M. Gil-Lafuente, J. Gil-Lafuente, \& J. M. Merigó-Lindahl (Eds.), Soft computing in management and business economics (Vol. 287, pp. 97-108). Berlin: Springer Berlin Heidelberg. http://dx.doi.org/10.1007/978-3-642-30451-4_7

Achcaoucaou, F., Miravitlles, P., \& Leon-Darder, F. (2014). Knowledge sharing and subsidiary R\&D mandate development: a matter of dual embeddedness. International Business Review, 23(1), 7690. http://dx.doi.org/10.1016/j.ibusrev.2013.08.006

Agência Nacional de Energia Elétrica. (2012). Manual do programa de pesquisa e desenvolvimento tecnológico do setor de energia elétrica. Agência Nacional de Energia Elétrica. Brasília: ANEEL.

Alejandro, V. A., \& Norman, A. G. (2005). Manual introdutório à análise de redes sociais. Toluca: Universidad Autonoma Del Estado de Mexico.

Almeida, P., \& Phene, A. (2004). Subsidiaries and knowledge creation: the influence of the MNC and host country on innovation. Strategic Management Journal, 25(8-9), 847-864. http://dx.doi.org/10.1002/smj.388

Amato, J., Neto. (2000). Redes de cooperação produtiva e clusters regionais. São Paulo: Atlas.

Ambos, T. C., Andersson, U., \& Birkinshaw, J. (2010). What are the consequences of initiative-taking in multinational subsidiaries? Journal of International Business Studies, 41(7), 1099-1118. http://dx.doi.org/10.1057/jibs.2010.19

Andersson U. (2003). Managing the transfer of capabilities within multinational corporations: the dual role of the subsidiary. Scandinavian Journal of Management, 19(4), 425-442. http://dx.doi.org/10.1016/S0956-5221(03)00040-X

Andersson, U., Dellestrand, H., \& Pedersen, T. (2014). The contribution of local environments to competence creation in multinational enterprises. Long Range Planning, 47(1-2), 87-99. http://dx.doi.org/10.1016/j.lrp.2013.10.002

Andersson, U., Forsgren, M., \& Holm, U. (2002). The strategic impact of external networks: subsidiary performance and competence development in the multinational corporation. Strategic Management Journal, 23(11), 979-996. http://dx.doi.org/10.1002/smj.267

Ariffin, N., \& Bell, M. (1999). Firms, politics and political economy: patterns of subsidiary-parent linkages and technological capability-building in electronics TNC subsidiaries in Malaysia. In K. 
S. Jomo, G. Felker, \& R. Rasiah (Eds.), Industrial technology development in Malaysia (pp. 150190). New York: Routledge.

Balestrin, A., Verschoore, J. R., \& Reyes, E., Jr. (2010). O campo de estudo sobre redes de cooperação interorganizacional no Brasil. Revista de Administração Contemporânea, 14(3), 458-477. Retrieved from http://www.scielo.br/pdf/rac/v14n3/v14n3a05.pdf. http://dx.doi.org/10.1590/S1415-65552010000300005

Barnes, J. A. (1954). Class and committees in a Norwegian island parish. Human Relations, 7(1), 3958. http://dx.doi.org/10.1177\%2F001872675400700102

Blomkvist, K., Kappen, P., \& Zander, I. (2010). Quo vadis? The entry into new technologies in advanced foreign subsidiaries of the multinational enterprise. Journal of International Business Studies, 41(9), 1525-1549. http://dx.doi.org/10.1057/jibs.2010.22

Cantwell, J. A., \& Mudambi, R. (2011). Physical attraction and the geography of knowledge sourcing in multinational enterprises. Global Strategy Journal, 1(3-4), 206-232. http://dx.doi.org/10.1002/gsj.24

Casarotto, N. E., Filho, \& Pires, L. H. (1998). Redes de pequenas e médias empresas e desenvolvimento local: estratégias para a conquista da competitividade global com base na experiência italiana. São Paulo: Atlas.

Chang, Y. Y., Mellahi, K., \& Wilkinson, A. (2009). Control of subsidiaries of MNCs from emerging economies in developed countries: the case of Taiwanese MNCs in the UK. The International $\begin{array}{llll}\text { Journal of Human Resource } & \text { Management, 20(1), }\end{array}$ http://dx.doi.org/10.1080/09585190802528383

Franco, C. (2014). Relação entre subsidiárias de energia elétrica e pequenas e médias empresas (PMEs) nos estados do Rio de Janeiro e Ceará: fatores determinantes da evolução das capacidades tecnológicas (Dissertação de mestrado). Universidade Estadual do Ceará, Fortaleza, CE, Brasil.

Freeman, C. (2004). The development of social network analysis: a study in the sociology of science. Vancouver: Empirical Press.

Granovetter, M. S. (1985). Economic action and social structure: the problem of embeddedness. American Journal of Sociology, 91(3), 481-510. http://dx.doi.org/10.1086/228311

Gulati, R. (1998). Alliances and networks. Strategic Management Journal, 19(4), 293-317. http://dx.doi.org/10.1002/(SICI)1097-0266(199804)19:4<293::AID-SMJ982>3.0.CO;2-M

Håkansson, H., \& Johanson, J. (1988). Formal and informal cooperation strategies in international industrial networks. In F. J. Contractor \& P. Lorange (Eds.), Cooperative strategies in international business (pp. 369-379). Lexington, MA and Toronto: Heath, Lexington.

Johanson, J., \& Vahlne, J.-E. (1977). The internationalization process of the firm-a model of knowledge development and increasing foreign market commitments. Journal of International Business Studies, 8(1), 23-32. http://dx.doi.org/10.1057/palgrave.jibs.8490676

Lee, R. P. (2010). Extending the environment-strategy-performance framework: the roles of multinational corporation network strength, market responsiveness, and product innovation. Journal of International Marketing, 18(4), 58-73. http://dx.doi.org/10.1509/jimk.18.4.58

Lee, S.-H., \& Song, S. (2012). Host country uncertainty, intra-MNC production shifts, and subsidiary performance. Strategic Management Journal, 33(11), 1331-1340. http://dx.doi.org/10.1002/smj.1982 
Lei n. 9.991, de 24 de julho de 2000. (2000). Dispõe sobre realização de investimentos em pesquisa e desenvolvimento e em eficiência energética por parte das empresas concessionárias, permissionárias e autorizadas do setor de energia elétrica, e da outras providências. Retrieved from http://www2.camara.leg.br/legin/fed/lei/2000/lei-9991-24-julho-2000-359823normaatualizada-pl.html

Liu, J., \& Chaminade, C. (2010). Dynamics of a technological innovator network and its impact on technological performance. Innovation Management Policy and Practice, 12(1), 53-74. http://dx.doi.org/10.5172/impp.12.1.53

Lorenzen, M., \& Mudambi, R. (2013). Clusters, connectivity and catch-up: Bollywood and Bangalore in the global economy. Journal of Economic Geography, 13(3), 501-534. https://doi.org/10.1093/jeg/lbs017

Mudambi, R., Pedersen, T., \& Andersson, U. (2014). How subsidiaries gain power in multinational corporations. Journal of World Business, 49(1), 101-113. http://dx.doi.org/10.1016/j.jwb.2013.02.001

Phene, A., \& Almeida, P. (2008). Innovation in multinational subsidiaries: the role of knowledge assimilation and subsidiary capabilities. Journal of International Business Studies, 39(5), 901919. http://dx.doi.org/10.1057/palgrave.jibs.8400383

Rossoni, L., \& Graeml. A. R. (2009, junho). A influência da imersão institucional e regional na cooperação entre pesquisadores do campo da administração da informação do Brasil. Anais do Encontro de Administração da Informação, Recife, PE, Brasil, 2.

Santangelo, G. D. (2009). MNCs and linkages creation: evidence from a peripheral area. Journal of World Business, 44(2), 192-205. http://dx.doi.org/10.1016/j.jwb.2008.05.009

Schifrin, M. (2001, May 21). Is your company magnetic? Forbes Best of the Web, 16-30.

Scott, J. (2000). Social network analysis: a handbook (2nd ed.). London: Sage Publications.

Yamin, M., \& Andersson, U. (2011). Subsidiary importance in the MNC: what role does internal embeddedness play? International Business Review, 20(2), 151-162. http://dx.doi.org/10.1016/j.ibusrev.2010.07.005

Yoruk, E. (2011). The influence of technological capabilities on knowledge network component of innovation systems: evidence from advanced materials. International Journal of Technological Learning, Innovation and Development, 4(4), 330-362. http://dx.doi.org/10.1504/IJTLID.2011.044141

\section{Authors' Profiles}

Camila Franco

Rua Pascoal Lemme, 355, Ilha do Fundão, Cidade Universitária, 21941-918, Rio de Janeiro, RJ, Brazil. E-mail address: camila.franco@coppead.ufrj.br

Samuel Façanha Câmara

Av. Dr. Silas Muguba, 1700, Campus do Itaperi, 60740-000, Fortaleza, CE, Brazil. E-mail address: sfcamara2000@ gmail.com

Ronaldo Couto Parente

Modesto A. Maidique Campus, 11200 S.W. 8th St, MANGO 437, Miami, FL 33199, USA. E-mail address: ronaldoparente@gmail.com 


\section{Corrigendum}

As per the authors' request, we inform that in document "Networks, R\&D projects and subsidiary behavior in a host country", http://dx.doi.org/10.1590/1807-7692bar2017160093, published in BAR Brazilian Administration Review, 14(1), e160093, page 1, the correct affiliations of author Ronaldo Parente are Florida International University and Fundação Getulio Vargas, Escola Brasileira de Administração Pública e de Empresas.

\section{Where it reads:}

Ronaldo Couto Parente ${ }^{3}$

Florida International University ${ }^{3}$

\section{It should read:}

Ronaldo Couto Parente ${ }^{3,4}$

Florida International University ${ }^{3}$

Fundação Getulio Vargas, Escola Brasileira de Administração Pública e de Empresas ${ }^{4}$ 